\title{
Por que dançar? Seis perguntas que resguardam uma forma de arte que não nos pertence
}

Autor: Arnd Wesemann1

Tradução: Luiza Banov

\section{Se você se interessa por coreografia,}

Existem quatro maneiras de observá-la. A primeira é no teatro. Aqui a dança muitas vezes é apresentada a sua própria maneira, às vezes juntamente com ópera, operetas ou musicais. Possui sua própria realeza, como Pina Bausch, quem criou a dança teatral, a partir da mera situação de se dançar em um teatro. Existe também a dança que quer ser vista como arte; muitas vezes isso significa que não existe dança em dança contemporânea, ao invés disso, é denominada de performance. Desta maneira, a dança aborda arte e trabalho - como um cumprimento ou desempenho (performance) de uma tarefa. É neste sentido que a dança pode ser compreendida como uma competição esportiva, algo que forma a base de uma carreira no balé assim como provoca uma batalha com o hip hop e aparece como seleção final dos candidatos de programas de TV, nos quais, assim como na patinação no gelo, existem apenas ganhadores ou perdedores. Finalmente, todos devem ao menos ter ouvido sobre o fato de que a dança pode ser simplesmente dançada, assim como em uma festa. Se ninguém dançar em uma festa, será uma festa deprimente. Mas o que é mesmo deprimente é que nossa cultura apóia a competição, a performance e o teatro - entretanto, as festas pertencem a uma cultura completamente diferente. Sendo o aposto de um trabalho (competição, performance, representação), elas não possuem mais status algum.

\footnotetext{
1 Arnd Wesemann, nascido em 1961 é editor da revista "tanz". em Berlim/Alemanha. Depois de concluir seus estudos em Jornalismo, escreveu uma monografia sobre o artista avantgardista de Flandres Jan Fabre. É entusiasmado com as novas mídias e suas relações com o corpo; e atualmente tem dúvidas se a dança deve ter suas origens no teatro.
} 


\section{A festa não possui status}

Ela custa dinheiro, demanda responsabilidade por parte dos convidados, pode ser consumida, pela razão de ser uma resposta ao consumo. A festa é a contrapartida de um presente - eu the presenteio você me dá uma festa. Eu faço algum tipo de sacrifício, você me ajuda em um jogo, uma dança, uma refeição, um drink, um novo conhecimento. Isto é muito maior que meu pequeno sacrifício; um buque de flores ou qualquer outro gesto com o qual eu possa aparecer. Você precisa superar meu presente porque é seu aniversário. A festa pode custar mais que a bicicleta com a qual você foi presenteado. Absurdo. Porque tal festa deve ser considerada cultura? Especialmente, uma vez que a festa foi há tempos recolocada por outra cultura, a do teatro, do filme uma cultura razoável que fazia um dinheiro razoável. Cultura atualmente, no sentido da palavra, adiciona uma troca justa em favor da cultura: gaste seu dinheiro em educação e entretenimento para ser educado e entretido (como necessário). Isto é exatamente o que uma festa não pode fazer. $E$ isto é o porquê que saber como celebrar com uma festa - como estar atento aos amigos das festas e gostar de sua companhia - não faz parte do nosso conceito de cultura.

\section{A cultura do conhecimento}

É o mote de hoje. Essa idéia indiretamente assume que deve haver uma cultura que saiba pouco ou quase nada. O carnaval, por exemplo: O que é que ele sabe? $\mathrm{O}$ que é que ele educa? Ou a dança, que geralmente é considerada muda, pois não se utiliza de palavras. Mas é a dança, não o carnaval que foi escolhida pelas políticas artísticas a ser portadora do conhecimento; o conhecimento de como saber dançar. Porque a dança, seja enquanto aula de balé, em uma escola elementar ou as aulas de dança de salão para a terceira idade, possui algo que obedientemente sobreviveu aos séculos: a maestria dos passos. Dançar não é dar pulos em volta em um aniversário infantil, não é aquecer crianças para uma celebração, não é a coreografia de uma série de novos jogos que façam com que as mesmas caiam em exaustão feliz. É o controle racional do próprio corpo, no qual quando certo nível de especialidades é alcançado, pode ser até mesmo apresentado em um teatro - a instituição - que racionalmente preserva o conhecimento em corpos vivos, enquanto o carnaval e festas de dança foram desvinculadas da nossa cultura hereditária e passadas para as mãos de seus patrocinadores. E então as festas tornam-se crescentemente particulares - e a 
dança é mais e mais realizada com financiamento publico. Uma linha foi traçada entre duas coisas que certa vez pertenceram juntas: entre a dança e a festa, entre a arte e a festa, mesmo entre o publico e sua festa.

\section{Performance}

É a chave. Já que as festas foram completamente privatizadas e os teatros completamente entregue às mãos do publico, verdadeiramente teatros privados ${ }^{2}$ são tão raros quanto as festas que são independentes da vontade de seus donos. Existe uma razão prática para isto. Pegue, por exemplo, o aniversário de uma criança: os pais devem realizar uma boa performance de si mesmos, ou ao invés de uma festa, eles tratam a si mesmos e às crianças com um pouco da cultura que "performa" (no sentido de atuação). Isto é enganosamente denominado "cultura de classe-média", mesmo que a classe média assista apenas à performances no palco que eles mesmos se recusam a realizar. De fato, a cultura do teatro permite à classe media se manter afora de sua própria cultura, a qual eles rapidamente se enganam em denominar arte. Eles querem um show o qual pagaram para assistir, deve ser estrangeiro, exótico, algo "diferente"... mas certamente não deve interferir em seu mundo. Um balé romântico de um passado distante, a cultura alienada do hip hop, um show realizado pelos sapateadores Irlandeses, tudo que fale a eles de mundos nos quais eles não possam habitar, porque lhes falta o corpo necessário para dançar como aqueles que dançam no palco. Eles admiram isto. Este tipo de entretenimento ganhou nome em 1990 pelo filósofo austríaco, Robert Pfaller, "interpassividade": "Eu não danço; eu deixo que outras pessoas dancem. Em uma verdadeira festa de classe-media isso seria verdadeiramente impossível.

\section{O consumidor de classe media}

Diz: "e daí?". Sua festa é agora seu teatro. Melhor ainda que isso: ele pode finalmente abandonar sua atuação ativa anterior em uma festa para uma postura de representação, de um dançarino ou ator no palco. O teatro é financiado e em troca, ele deve assistir o que deseja. Ou não, uma vez que ele não é mais limitado à tradição de lidar com esta despesa considerável de si mesmo; ter que investir em um castelo de madeira, encontrar novas fantasias para seus descendentes e oferecer comes e bebes.

\footnotetext{
${ }^{2}$ N.E. O autor do texto se refere a uma situação pouco comum na Alemanha a existência de teatros privados. Outro sim naquele país os teatros são quase na sua totalidade mantidos com financiamentos oriundos da prefeitura da cidade, ou ainda provenientes de financiamentos oriundos da capital regional .
} 
Agora, pelo contrario, ele é o guarda livros, que vê neste teatro o mesmo desprendimento com que ele vê o seu próprio negócio: como uma operação com fins lucrativos, com representantes contratados de seu trabalho perdido não mais obrigados a cantar, atuar e dançar a si mesmo. Ele não mais necessita ser capaz de fazer aquilo. Para ele, parece que ele se doa completamente para esta cultura a qual ele deixou à prefeitura da cidade e seu departamento de contas já que ele não mais celebra esta cultura. Ele prefere celebrar suas derrotas em um campo de esportes, velando a falta de sorte de seu time e fazendo uma festa de qualquer ponto marcado. No jogo, ele redescobre o que ele perdeu no teatro: sua própria participação no espetáculo.

\section{Omitido}

É o que o publico é - deixado em quase que uma posição extraterrestre. Sua crença profunda na beira do palco faz com que ele retrate. Uma borda invisível é desenhada, mesmo a frente do menor palco. Mesmo na primeira fileira, na qual a platéia se coloca bem em frente, nos pés dos dançarinos, a regra é aplicada: nem mais um passo adiante. A área do palco é sagrada. Essa margem imaginaria, a moldura do palco, separa tudo o que acompanha uma festa. Um lugar como um púlpito ou um altar é criado, e que nitidamente separa o espaço e, ao invés de permitir uma verdadeira participação, por exemplo, participação física, quer recrear uma realidade pensada, com emoções controladas. O que mais o publico deve fazer ali, a não ser pensar para si mesmo? O teatro imobiliza o corpo, enquanto os corpos que ainda se movem, no palco, corporificam outra coisa - muito no sentido de entender, em outras palavras não se posicionar. Dançar. Depois de tudo³.

\footnotetext{
${ }^{3}$ Neste paragrafo o autor faz um trocadilho com a palavra "understanding" (entender) separado esta palavra dando um sentido de uma posição inferior.
} 


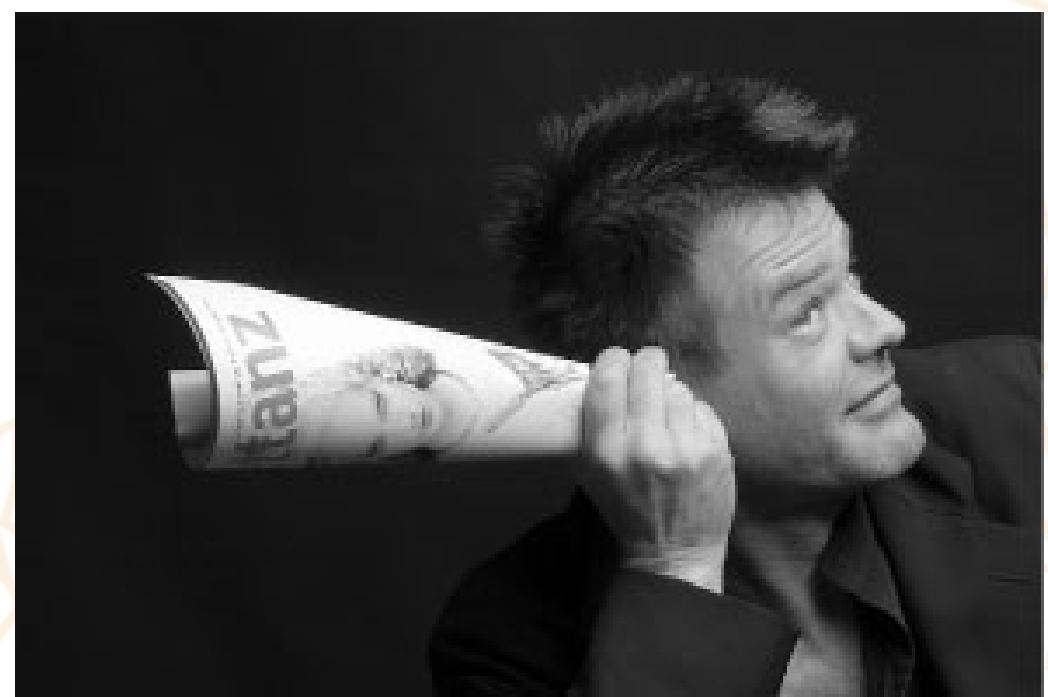

Foto@Bettina Stöß

\section{Outros links úteis}

Revista Tanz

"cultura de classe-média"

Robert Pfaller, "interpassividade"

No jogo, ele redescobre o que ele perdeu no teatro: sua própria participação no espetáculo. 